Revista Signos

2010, 43(73)

$261-280$

\section{Appraisal in the research genres: An analysis of grant proposals by Argentinean researchers}

\author{
Mariana Pascual \\ Lidia Unger \\ Universidad Nacional de San Luis \\ Argentina
}

\begin{abstract}
Writing an effective grant proposal poses many challenges for researchers, in particular for those whose native language is not English and who may have received little formal instruction in writing. While considerable research has been undertaken on the genre of the research article, grant proposals have received much less attention, despite their major significance in research settings. This study aims at investigating how grant proposal writers in the disciplines of chemistry and physics position themselves in relation to other researchers and theorists in key obligatory stages of this genre, namely Benefits and Importance Claim (Connor \& Mauranen, 1999). Two successful and praiseworthy examples from disciplinary areas where access to international funding is regarded as important are analyzed. They were written by Argentinean non-native English speakers working at the Universidad Nacional de San Luis. The proposals are analyzed by using the Appraisal framework proposed by Martin (2000) and Martin and White (2005), with a focus on the system of ENGAGEMENT. Results indicate that the proposals were highly heteroglossic, and that a variety of ENGAGEMENT resources were used. The instances were predominantly expansive, suggesting that authors tend to invite rather than challenge their colleagues' views. This may be interpreted as an attempt to address a potentially varied audience. These results can assist authors in becoming aware of the interpersonal resources they may use to position themselves and align their audiences when writing their grant proposals.
\end{abstract}

Key Words: Research genres, grant proposal, systemic functional linguistics, appraisal, engagement.
Recibido: 15-VII-2008 Aceptado: 25-III-2010
Correspondencia: Mariana Pascual (pascualm@unsl.edu.ar). Centro de Lenguas Extranjeras, Universidad Nacional de San Luis. Ejército de los Andes 950, San Luis, Argentina. 


\section{La valoración en géneros científicos: Un análisis de solicitudes de fondos para investigación de escritores argentinos}

Resumen: Los investigadores no nativos del idioma inglés deben enfrentar muchos desafíos al elaborar sus solicitudes de fondos para investigación, en particular, aquellos que no han recibido una capacitación sistemática en escritura. Los estudios sobre los significados interpersonales en géneros científicos desde la perspectiva Sistémico-Funcional se han ocupado principalmente del artículo de investigación. Sin embargo, y a pesar de su importancia en ámbitos académicos, otros géneros no han atraído tanta atención. Este trabajo indaga acerca de la manera en que los escritores de solicitudes de fondos de investigación de las disciplinas de Química y Física se posicionan frente a sus colegas, en las etapas obligatorias de este género: Beneficios y Declaración de Importancia (Connor \& Mauranen, 1999). Se analizan dos solicitudes que cumplieron acabadamente con su objetivo. Fueron escritas por investigadores argentinos hispanohablantes de la Universidad Nacional de San Luis, al momento de solicitar financiamiento de agencias internacionales. El análisis se basó en la teoría de la Valoración, según Martin (2000) y Martin y White (2005), focalizándose en el sistema de Involucramiento. Los resultados dan cuenta de textos altamente heteroglósicos y una amplia variedad de recursos de Involucramiento. Las instancias identificadas son predominantemente expansivas, lo cual sugiere que los autores tienden a invitar, más que a desafiar los posicionamientos de sus colegas. Esto se interpretaría como un intento de dirigirse a una audiencia potencialmente variada. Estos resultados pueden ayudar a los investigadores a tomar conciencia de los recursos interpersonales disponibles para posicionarse más efectivamente frente a sus producciones y a sus audiencias.

Palabras Clave: Géneros científicos, solicitud de fondos para investigación, lingüística sistémicofuncional, valoración, discurso académico.

\section{INTRODUCTION}

Studies of evaluative meanings carried out on research genres have mainly focused on the research article (see Hunston, 1993; Hyland, 1998a, 1998b; Martínez, 2001, 2003; Myers, 1989; Salager-Meyer, 1990, 1994, 1997). However, some other genres, such as the grant proposal, have not received much attention, despite their major significance in research settings. Writing an effective grant proposal poses many challenges for non-native English speakers (NNESs), especially for those who have not received much systematic training in academic and scientific genres.

Previous studies on evaluation in grant proposals adopted a pragmatic perspective, providing intuitive interpretations of texts without the support of a meaning-based theory of language. Studies of this kind, such as the ones conducted by Myers (1990, 1991), Johns (1993) and Connor and Mauranen (1999), have offered valuable insights into evaluation. This theoretical perspective seems to lead to some lack of clarity, arising from the definition of discourse as an 
information or content transmitting vehicle. On the same theoretical lines, 'hedging' is considered as a set of resources, which function interpersonally at the grammatical level (Hyland, 2000). Regarding this concept, Hood (2004: 30) claims that there is a need: "to account for the other functions of the text as doing positioning, politeness, arguing or alignment work, and to account for the writer's construction of the text as a message as somehow outside of discourse proper".

Thus, more comprehensive accounts of language, such as the ones proposed by Systemic Functional Linguistics (SFL) (Halliday, 1985, 1994; Martin, 1992; Halliday \& Matthiessen, 2004), may prove particularly valuable to the study of the functioning of language.

The present study attempts to explore expressions of interpersonal meaning more systematically, drawing on SFL theory. The metafunctional nature of this theory not only provides a systematic means for differentiating interpersonal meaning from ideational and textual meanings, but also for exploring how they relate to each other. Within SFL, Appraisal offers the theorization of interpersonal meaning choices in discourse (see Martin, 2000; Martin \& Rose, 2003, 2007; Hood, 2004; Hood \& Martin, 2005; Martin \& White, 2005). A central concept of Appraisal theory is that speakers of a language use evaluative resources "for negotiating our social relationships, by telling our listeners or readers how we feel about things and people (in a word, what our attitudes are)" (Martin \& Rose, 2003:19). The focus of analysis of this study deals with one of the Appraisal systems outlined by these authors -ENGAGEMENT, which includes "all the resources by which the textual or authorial voice is positioned intersubjectively" (White, 2001:14). Though previous studies have focused on the research genres following the framework of Appraisal (see Hood, 2004; Hood \& Martin, 2005), or on the specific system of ENGAGEMENT but in other non-academic genres (see Miller, 2004), to our knowledge, no research has been conducted using grant proposals written by NNESs.

This study aims at investigating successful grant proposals produced by Argentinean NNESs working at the Universidad Nacional de San Luis (UNSL) in the disciplines of Chemistry and Physics, in order to examine how they position themselves in relation to other researchers and theorists in key obligatory stages of this genre, namely Benefits (B) and Importance Claim (IC). The notion of 'successful' is here interpreted in terms of effectiveness, i.e. of the accomplishment of the social purpose of grant proposals, regardless of considerations as to the 'quality' of the discourse produced. Results are expected to throw some light on researchers' writing practices and thus promote their linguistic awareness of the interpersonal resources they may use when writing. In keeping with these concepts, it is hoped that their written productions and their interaction with other members of the scientific community are ultimately improved. 


\section{Research genres: The grant proposal}

Research on academic written discourse (Swales, 1990, 1996; Hyland, 1998a, 1998b, 2000, 2004; Connor \& Mauranen, 1999) has mainly focused on the most popular academic genres, such as the research article and the abstract. Nevertheless, some valuable contributions have been reported to the study of the grant proposal genre by Myers (1990, 1991), Johns (1993), Connor and Mauranen (1999), and Ponticelli, Pascual and Unger (2005).

According to Connor and Mauranen (1999), grant proposals represent a type of persuasive writing whose communicative purpose is to convince reviewers and funding agencies to provide them with the funds they require to carry out their research activities. Following Swales' definition of move (1990), these authors identify ten rhetorical moves, namely Territory, Gap, Goal, Means, Reporting Previous Research, Achievements, Benefits, Competence Claim, Importance Claim and Compliance Claim. Within these identifiable functional units, they concluded that the following moves -or stages- were specific to the genre: Achievements, Benefits, Importance Claim and Compliance Claim. The first two refer to the purposes of the research - whether they contribute to the research or outside world, respectively. Like in the previous moves, Importance Claim seeks to emphasize the positive aspects of the work but it is not in a strict relationship to the results. The last special move-Compliance Claim- seems to be specific to European Union programs. It addresses the requirements and goals of particular European funding agencies. Therefore, the two stages selected for analysis in this study are Benefits (B) and Importance Claim (IC), which are regarded as highly persuasive (Connor \& Mauranen, 1999).

Although the studies carried out by Connor and Mauranen (1999) provide a valuable description of grant proposals, the limitations imposed by the pragmatic type of analysis make them inadequate for a meaning-based study of interpersonal resources such as the one we report in this work. In consequence, the move analysis presented above is only regarded here as a descriptive starting point. Our study eminently draws on the SFL framework, which provides efficient analytical and interpretative tools. Thus, departing from Connor and Mauranen's assumption and with the assistance of the SFL tools, we attempt to discover how authors construe their persuasive stances in texts, and provide an evaluation of persuasion by exploring how they manage to do so.

Writing is an act of persuasion, and the lexico-grammatical choices used for constructing discourse and, in particular, for constructing stance or position, have unquestionable effects on the act of communication that may be most evidently observed in these stages of the genre. Pragmatic scholars who have studied interpersonal meanings, such as Hyland (1998a, 1998b) and Salager-Meyer $(1990,1997)$, identify position through metadiscourse instances and thus 
propose a taxonomy of main linguistic resources that realize stance. The categorizations proposed by these authors include hedges, boosters, attitude, relational and personal markers. However, other scholars from the SFL perspective (see Martin \& White, 2005; White, 2002, 2003a, 2003b; Martin \& Rose, 2003, 2007) have moved beyond these classifications and placed all instances of interpersonal positioning within the broader framework of Appraisal theory.

\section{Appraisal theory}

Unlike studies carried out by authors working in pragmatic frameworks (see Hyland, 1996a, 1996b, 1998a, 1998b, 2000, 2004; Connor \& Mauranen, 1999; Salager-Meyer, 1990, 1997), the focus of scholars within the Systemic Functional theory is not so much on the grammatical components that realize interpersonal meanings but on the semantics of intersubjective positioning. One of the main strengths of the SFL perspective is that it offers a comprehensive view of evaluative resources, including instances of attitude and positioning and the sources of these evaluative stances in discourse. SFL provides a model which allows us to systematically relate lexico-grammatical choices to the construction of different meanings on the basis of its theoretical principles.

Within this framework, Appraisal has been defined as “ $[\ldots]$ the semantic resources used to negotiate emotions, judgments and valuations, alongside resources for amplifying and engaging with these evaluations" (Martin, 2000: 145). This theory was developed with the main purpose of analyzing the resources of intersubjective stance (White, 2003a) and to trace:

[...] a comprehensive map of appraisal resources that we could deploy systematically in discourse analysis, both with a view to understanding the rhetorical effect of evaluative lexis as texts unfold, and to better understanding the interplay of interpersonal meaning and social relations in the model of language and the social we were developing, especially in the area of solidarity (Martin, 2000: 148).

The theory of Appraisal proposes a taxonomy which includes the systems of ATTITUDE, ENGAGEMENT and GRADUATION. ATTITUDE refers to "our feelings, including emotional reactions, judgments of behavior and evaluation of things" (Martin \& White, 2005: 35). This system is, in turn, divided into three categories: AFFECT, JUDGEMENT and APPRECIATION. AFFECT is defined in terms of "resources for expressing feelings" whereas JUDGEMENT refers to "resources for judging character", and APPRECIATION to "resources for valuing the worth of things" (Martin \& Rose, 2003: 24).

The system of ATTITUDE constitutes the main resource for evaluating, adopting stances, con- 
structing textual personas and managing interpersonal positionings and relationships. The other two systems -GRADUATION and ENGAGEMENT- are considered attendant systems which contribute to the core one and may function simultaneously.

The system of GRADUATION encompasses those resources which strengthen or weaken attitude, resources for "adjusting the volume" of items (Martin \& Rose, 2003: 41). GRADUATION is subdivided into Force (the strengthening or weakening of the degree of evaluation) and Focus (the sharpening or softening of boundaries between categories in the context of non-gradable items).

ENGAGEMENT deals with sourcing attitudes and the play of voices around opinions in discourse. According to White (2001), this system covers all the resources that the language offers for speakers to express their interpersonal positionings in the texts they produce. This author also specifies that the scope of this system is greater than what is traditionally included under the labels modality, evidentiality and hedging but narrower than what is identified as metadiscourse in other frameworks. Figure 1 illustrates the main systems through which speakers construct appraisal.

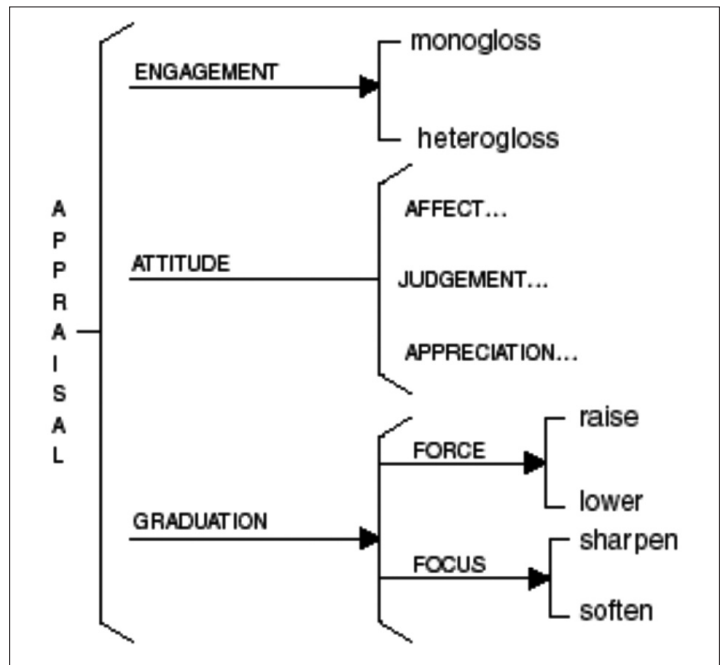

Figure 1. Appraisal System (Martin \& White, 2005).

The focus of this paper relates to the system of ENGAGEMENT, since it is an aspect of vital importance for the genre under study -the grant proposal. The first reason that justifies the 
choice of this system is our adherence to Bakhtin (1982) and Vološinov's (1973 [1929]) notion that all verbal communication is dialogic. In the case of academic writing, there is an evident interplay of discourses in which the author struggles to obtain and maintain room and consensus within the scientific community (Hood \& Martin, 2005). The second reason refers to the highly interactive nature of this genre and its predominantly persuasive communicative purpose, by which authors try to convince a funding agency that the work they are planning to do is relevant for the development of science and worth financial support.

The system of ENGAGEMENT, as mentioned above, is related to: "Those meanings which in various ways construe for the text a heteroglossic backdrop of prior utterances, alternative viewpoints and anticipated responses" (Martin \& White, 2005: 97).

The point of departure for this system is the distinction between the monoglossic utterance or undialogized bare assertion and the heteroglossic or dialogistic one, which signals an alternative position or source.

Instances of heteroglossic utterances are further subdivided on the basis of

"the degree to which an utterance, by dint of one or more of these locutions actively makes allowances for dialogically alternative positions and voices (dialogic expansion) or alternatively acts to challenge, fend off or restrict the scope of such (dialogic contraction)" (Martin \& White, 2005: 102).

Figure 2 outlines these two dialogic orientations.

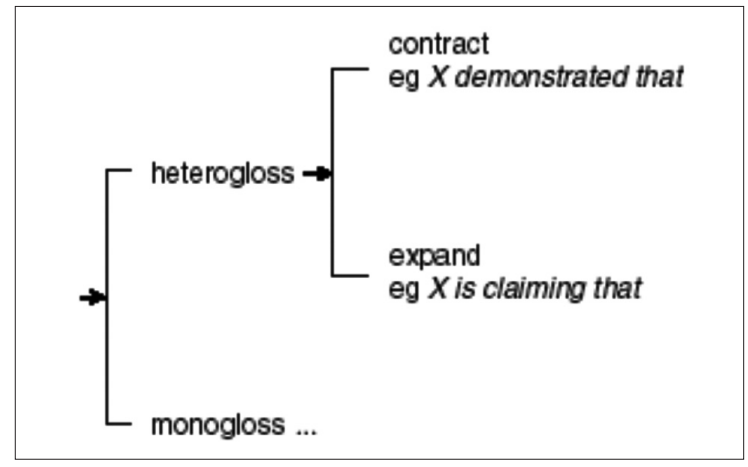

Figure 2. System of ENGAGEMENT: Dialogic contraction and expansion. 
The first type -Contract- is further divided into two main subcategories: disclaim and proclaim. These notions refer to whether the dialogic space is open for subsequent alternative voices -or whether it rules out subsequent dialogic instances and disclaim- proclaim. The former is divided into two subtypes: deny (e.g. 'The action won't damage the trust between the President and his body guards') and counter (e.g. 'Amazingly, this damaged the trust between the President and his body guards'). ${ }^{1}$

When authors choose to deny, they introduce an external voice so as to acknowledge it, and then present a negative orientation to reject it. Through counter, authors also invoke a contrary position to the one introduced, but unlike deny, they do so by introducing a proposition which replaces or substitutes the one expected.

The second subcategory within Contract -proclaim- includes those instances which "act to limit the scope of dialogistic alternatives in the ongoing colloquy" (Martin \& White, 2005: 121). Proclaim comprises three sub-types: concur, pronounce and endorse. Through concur, authors overtly state that they agree or share knowledge with the voice presented or with the audience. This subtype may be realized textually by means of interpersonal modal adjuncts such as 'of course',' naturally', 'obviously' and 'certainly', or through certain types of rhetorical questions. Pronounce refers to those instances in which the author intervenes overtly into the text so as to assert or emphasize the value of the proposition. Some examples include 'I contend that'..., 'The fact of the matter is that'..., 'really', 'indeed', etc. Through endorse, authors make reference to external sources, which are presented as unquestionable, valid or correct, thus ruling out subsequent negotiation. This category is realized by verbal processes or nominalized equivalents, such as 'experts have shown/demonstrated/found, the findings reveal', etc.

The other type of heteroglossic ENGAGEMENT is Expand, which includes two subtypes: entertain and attribute. This distinction is based on whether dialogic alternatives are presented as one of a number of possible positions -entertain, or attributed to an external source by showing agreement with it by means of a direct acknowledgement or claiming a distance from it.

Entertain may be realized lexico-grammatically by means of modals of probability ('may', 'might', 'perhaps', 'probably', 'it’s likely/ possible that', 'I think', 'I believe', 'it seems', 'apparently', 'research suggests', etc.), reality phase in Halliday's terms (1994) (e.g. 'appear to do', 'seem to do', 'prove to do') and interpersonal metaphors (e.g. 'in all probability', 'it is/ not likely', 'it is obvious that', etc.). As to attribute, it offers two ways in which the authorial voice is positioned in relation to the external source introduced, either by expressing alignment with it -acknowledgement, typically through the use of a reporting device ('say', 'report', 
'suggest', 'declare', etc.) or by establishing a distance from it (through some reporting verb, particularly through the use of 'claim'). Figure 3 shows the ways the language offers to realize heteroglossic engagement.

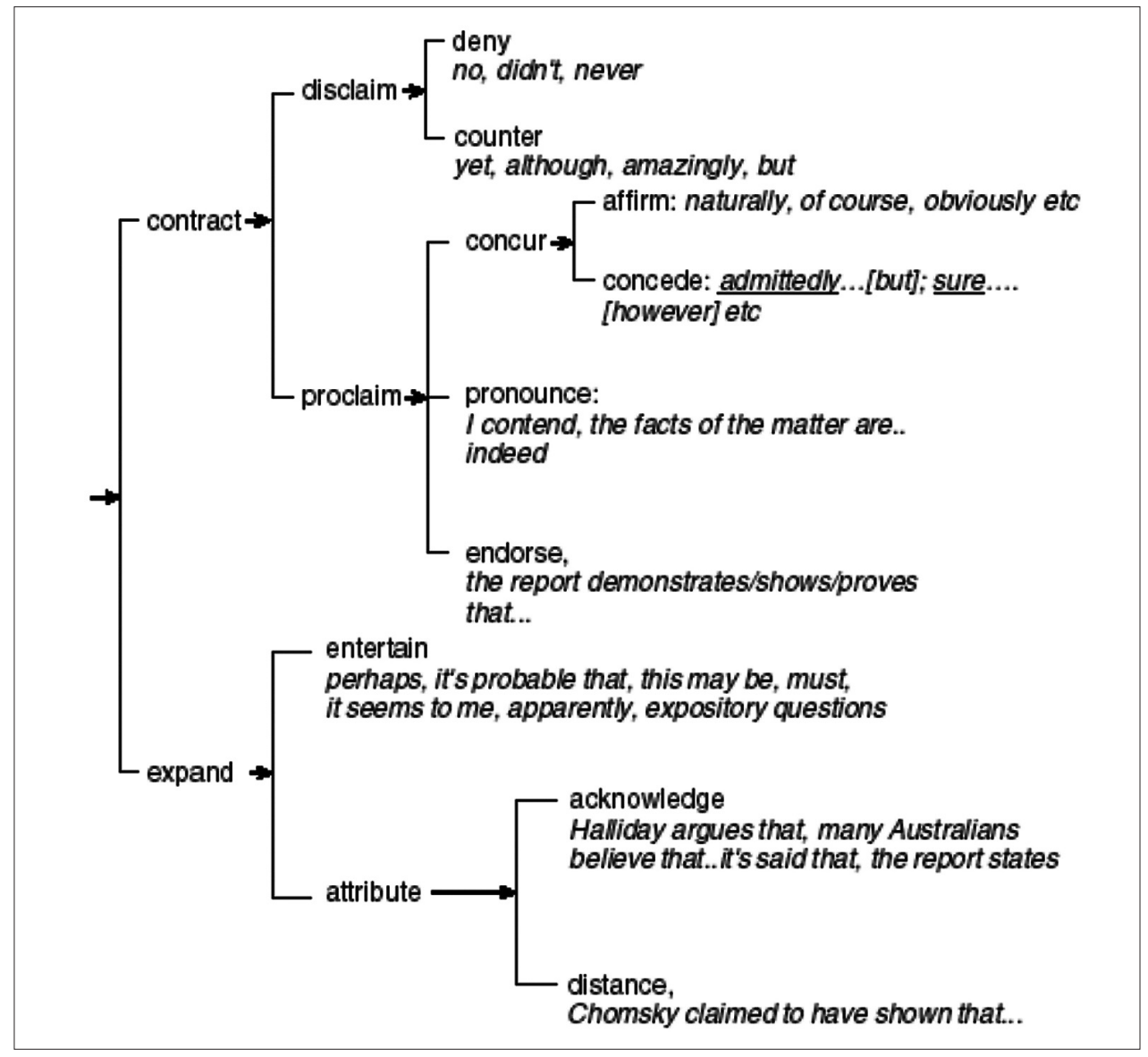

Figure 3. Heteglossia in discourse within the system of ENGAGEMENT (White, 2002: 10).

In this study, we focus on the system of ENGAGEMENT to show how Argentinean NNES researchers in the disciplines of Physics and Chemistry from the Universidad Nacional de San Luis (UNSL) 
establish an interpersonal position in the scientific community in their successful grant proposals, when applying for funds to support their research work.

\section{Context of the study}

Universidad Nacional de San Luis, located in the center of Argentina, comprises three main faculties in its central seat -1. Chemistry, Biochemistry and Pharmacy; 2. Physics, Mathematics and Natural Sciences; and 3. Human Sciences. Approximately 350 professionals carry out research on their disciplinary fields at this university. Most of them receive funding from national agencies such as CONICET (Consejo Nacional de Investigaciones Científicas y Técnicas) and SeCyT-UNSL (Secretaría de Ciencia y Técnica). However, some others also obtain financial support from international agencies, such as the US National Science Foundation (NSF) and the Third World Academy of Sciences (TWAS), among others.

Apart from thorough disciplinary knowledge, applying for these international agencies presupposes a fluent use of English and a high level of competence in the use of interpersonal resources on the part of the researchers. To help them achieve these language demands, English for Specific Purposes (ESP) teachers usually act as proofreaders, linguistic advisors and editors.

\section{Method}

This study is part of a larger research work of the Secretaría de Ciencia y Técnica, from the UNSL. In this context, we selected two grant proposals written by teacher-researchers who volunteered to provide their texts for study. Their disciplinary fields correspond to the so-called hard sciences, namely Chemistry and Physics. These two proposals were selected on the need to analyze texts representing the disciplines that generate the largest number of publications from the UNSL -Chemistry and Physics. Grant writers from these two disciplines are the main requesters of linguistic coaching and guidance in qualitative as well as quantitative terms. Moreover, these two proposals presented a great variety of interpersonal resources, constituting rich units for analysis. Both of them had achieved their objective, the authors not only obtained the requested funds to conduct their research, but their proposals were highly praised and evaluated by the international fund providers.

Out of the four special rhetorical stages identified as specific to the genre 'grant proposal' by Connor and Mauranen (1999), Benefits (B) and Importance Claim (IC) were selected because they correspond to highly persuasive stages; they were both present in the texts under study, 
and best fit the standardized generic features. With respect to the B stage, Connor and Mauranen (1999) specify that it is in this section of the text where the intended outcomes of the study are presented, in relation to their usefulness and value for the study itself, or for the discipline and the world outside. The following example taken from one of the proposals under analysis illustrates this stage. It appears under the section heading Background and Significance, while in the other proposal this stage appears under a section named Goals. Though the labeling of the proposal section may vary, it is clear that its rhetorical function is consistent with the defining features of the stage.

"In addition, calculations of the $\mathrm{C} \alpha$ and $\mathrm{C} \beta$ chiral shifts for a series or oligopeptides containing alanine with the sequences Ac-(Pro)3- Ala-(Pro)3-Gly-Tyr-NH2 (Kelly et al., 2001) and Ac-XX-(Ala)7-00-NH2 (Shi et al., 2002) will allow us to characterize more precisely the backbone conformation and, hence, provide a possible explanation and understanding of the existing disagreement between CD-derived data (Rucker and Creamer, 2002) and NMR vicinal coupling constant information (Shi et al., 2002)."

In the IC stage, writers state the significance of the study for which they are requesting funds, and pose its objectives and outcomes as really urgent and necessary for the outside world or for the discipline. The heading under which the following example appears is 'Long-term outlook', whereas in the other text, this stage is also included under Background and Significance.

The case has been made above for the urgent need to carry out basic research on chiral heterogeneous catalysis. This is a complex problem, and extensive work will be required before a general picture of the parameters that control enantioselectivity is to be generated.

After determining the textual segments which realized the B and IC stages, comprised approximately by 3000 words, an analysis of Appraisal was undertaken for each of the two selected stages. While analyses included attention to ATTITUDE and GRADUATION, this paper focuses on the choices writers made with respect to ENGAGEMENT.

\section{Results and discussion}

In this section, results are presented by category together with examples that illustrate them, ordered from the most general categories of ENGAGEMENT to the most discrete ones (see Figure 3). The following subsections introduce the results and discussion corresponding to the grant proposal writers' use of specific ENGAGEMENT resources across the two stages selected -B and IC. These results aim at shedding some light on what specific lexico-semantic choices these writers made, and in what stage of the text they decided to include them. 


\subsection{Introducing and managing voices}

The results of the analysis of the two texts indicate that the B and IC stages are eminently heteroglossic. Though these moves might be expected to focus heavily on the authorial voice, the presence of a multiplicity of voices is evidenced by nearly forty dialogic instances in the texts. A summary of the results of the analysis of heteroglossic instances found in the texts is shown in the table below.

Table 1. Overview of heteroglossic instances and types in the text.

\begin{tabular}{|c|c|c|c|c|}
\hline \multirow{8}{*}{ Heterogloss } & \multirow{5}{*}{ Contract } & \multirow{2}{*}{ disclaim } & deny & 3 \\
\hline & & & counter & 3 \\
\hline & & \multirow{3}{*}{ proclaim } & concur & 1 \\
\hline & & & pronounce & 6 \\
\hline & & & endorse & 1 \\
\hline & \multirow{3}{*}{ Expand } & entertain & & 20 \\
\hline & & \multirow{2}{*}{ attribute } & acknowledge & 4 \\
\hline & & & distance & 0 \\
\hline
\end{tabular}

The instances that realize the introduction and managing of other voices vary widely in lexicogrammatical form and degree of dialogism. Some of them are openly heteroglossic in the sense that they make an explicit reference to external voices or positions through projections -quotes or reports, as in the following example:

1. It has long been recognized that $\mathrm{Ca}$ and side-chain carbons of a given residue in statistical-coil peptides are not sequence dependent (Howarth \& Lilley, 1978).

It is noteworthy that a large number of non-integral citations was identified, showing some degree of heteroglossia, as a resource for grading up the value of a proposition. However, they were not considered in our analysis because they may be regarded as slightly evaluative in the genre, and in particular in the disciplines under analysis. Though profusely used by writers, the purpose of including this type of citation seems to constitute an attempt to build up on consensual disciplinary knowledge rather than engage in dialogism.

In some other cases, authors engage in a less direct dialogistic positioning through modality or counterexpectancies -through conjunctions, either concessives or continuatives (Martin \& Rose, 2003), for example:

2. These transitions are likely to be gradual, and need to be better understood. 
Following is the analysis of each of the heteroglossic categories within the framework of Appraisal -Contract and Expand, corresponding to whether authors restrict or entertain external voices, respectively. In the texts analyzed, there is an apparent tendency to use Expand over Contract. Results show that authors make use of both types of Expand -entertain as well as attribute. These writers used expansive forms far more frequently than contractive forms (twenty-four instances for Expand versus fourteen for Contract). Within Expand, the most frequent type was entertain. It may be worth mentioning that the voices engaged through this subcategory were agentless or vaguely incorporated to the discourse, as may be seen in the following examples:

3. ... small chiral molecules such as alcohols and amines are believed to create supramolecular templates

4. It appears that copper surfaces, ...

When other voices are entertained, the preferred structure used is / is + epistemic relational/ cognitive mental process to express the evaluation, with a highly impersonal, untraceable voice, as shown in the following examples:

5. It is known that $13 \mathrm{Ca}$ and $13 \mathrm{Cb}$ chemicals shifts are highly sensitive to backbone.

6. It is believed that backbone dihedral angles account for half or more of the observed variation.

7. It has also been suggested that: (a) $13 \mathrm{C}$ shifts are probably comparable to J vicinal coupling.

In cases in which writers made use of the other expansive subcategory, attribute, to show agreement with the positioning of other voices, four cases were identified, all corresponding to acknowledge, and they all refer to the researchers' own previous studies.

8. In a recent paper ... we report the results of a molecular dynamics study ...

9. Recent applications of this methodology ... have been very successful.

In brief, dialogic expansion constituted the preferred orientation to the heteroglossic variety of engagement and, within this option, entertain was the most frequently applied. This result indicates that these authors selected to open up dialogic space, representing the proposition as one of a range of possible positions while referencing other members of the scientific community, whose views are construed as possible and to various degrees authorized (White, 2002).

As for Contract, results show that this category is less frequently used, and, in turn, that both 
subcategories -disclaim and proclaim- appear in the texts with similar frequency as shown in Table 1 (six and eight instances, respectively). This result is in line with Miller's claim (2004) of the typicality of a mixture between these resources.

Within disclaim, when authors introduce an external voice and then reject or dismiss it, they seem not to resort to the subcategory deny. In only three out of the fourteen instances of dialogic contraction identified, the writers denied external voices, and the participants whose ideas were challenged are rather vague, as the following examples illustrate:

11. ... traditional approaches ... and molecular dynamics neglect this interdependency...

12. ... traditional approaches are quite simplistic and, in general, have failed to explain experimental observations.

In all cases, the disclamation by denial is realized through negative modal processes ('neglect', 'fail'). The function of the use of these resources seems not to offer a 'correct' view of real or potential alternative assumptions, but to emphasize the importance of the writers' contributions by establishing a contrast with what other members of the community have not yet achieved.

The other type of contractive disclamation is counter. In these cases, these proposal writers decided to introduce other voices to challenge them, ultimately strengthening their own position. Three instances were identified, realized through a conjunctive of time ('yet'), contrast ('however') and an adversative ('but'), as shown in the following examples:

13. ... the main problem that has yet to be solved...

14. ... such a characterization, however, has proven to be both difficult and sensitive...

15. ... statistical-coil C chemical shifts show small, but not zero.

Within the three subcategories corresponding to the other form of contractive dialogism, proclaim, the analysis also shows that these grant proposal writers most frequently resort to the use of pronounce. In six out of the eight cases found, this proclaiming resource was selected. In all cases, authors engage their own activities and voices rather than someone else's, as in these examples:

16. We plan to use a quantum chemical computation of the Boltzmann-averaged value.

17. ... three prototypical families ... will be explored in our initial studies.

With respect to concur, although it might be expected that researchers construe their 
theoretical positioning using lexicogrammatical forms that express concurrence with other colleagues' views, only one instance was identified.

18. ... in line with this observation, the ... experiment indicates that ...

When authors make use of endorse, they align themselves with some other voice which is construed as "correct, authoritative or otherwise argumentatively compelling" (White, 2003b: $3)$. In the texts under study, only one instance was found. In this case, the writer selected to use a combination of resources -both of a contractive type- to challenge other voices by means of a denial which is then endorsed, as may be seen below:

19. ... molecular dynamics neglect this interdependency by simply assuming that the charges .... are invariant.

All in all, there is a marked presence of expansive elements which have contributed to the dialogistic characters of the segments under study.

\subsection{Engagement resources across the $B$ and IC stages}

Once all instances of heteroglossic engagement were identified and categorized, they were related to the generic stage in which they had been included, either B or IC. Table 2 summarizes the occurence of ENGAGEMENT instances according to stage.

Table 2. Instances of heteroglossic ENGAGEMENT according to the stage in which they appear.

\begin{tabular}{|c|c|c|c|c|c|c|}
\hline & & & & B stage & IC stage & Total \\
\hline \multirow{8}{*}{ Heterogloss } & \multirow{5}{*}{ Contract } & \multirow{2}{*}{ disclaim } & deny & 0 & 3 & 3 \\
\hline & & & counter & 0 & 3 & 3 \\
\hline & & \multirow{3}{*}{ proclaim } & concur & 0 & 1 & 1 \\
\hline & & & pronounce & 3 & 6 & 6 \\
\hline & & & endorse & 0 & 1 & 1 \\
\hline & \multirow{3}{*}{ Expand } & \multicolumn{2}{|l|}{ entertain } & 1 & 19 & 20 \\
\hline & & \multirow{2}{*}{ attribute } & acknowledge & 1 & 3 & 4 \\
\hline & & & distance & 0 & 0 & 0 \\
\hline
\end{tabular}


Results show that the predominant type of heteroglossic engagement used was expansive, most instances being found in the IC stage. It seems that these proposal writers tend to engage other voices expansively in their discourse in the stage in which they establish the significance of the proposed work, rather than when expressing its usefulness.

This tendency -to be more expansively dialogistic in the IC stage- may be accounted for by the more 'local' type of argumentation presented in this stage. Other participants are engaged in a dialogue which is highly technical, in contrast to the more general nature of the benefits, which transcend disciplinary boundaries as well as the writers' scientific community, i.e. the benefits may refer to several types of impact other than scientific, such as social, ecological, environmental or industrial.

The contrasting placement of heteroglossic engagement -five instances in B versus thirty-three in the IC stage- might also be interpreted as an attempt on the part of the writers to address a potentially varied audience. Evaluating boards in funding agencies may be constituted not only by colleagues in a close symmetric relation in terms of disciplinary expertise, but also by other professionals from other competing areas or sub-areas of science who may expect a discourse more oriented towards general benefits, rather than a strictly scientific dialogue.

\section{Conclusions and pedagogical implications}

The objective postulated in the Introduction of this study was to investigate how Argentinean NNESs grant proposal writers working at the UNSL position themselves in relation to other researchers in two of the obligatory stages of this genre, and shed some light on their writing practices for pedagogical purposes.

When communicating with their peers in the international research community, these writers of successful grant proposals make use of a variety of strategies, showing a preference for expansive resources which invite rather than challenge their colleagues' views. On the same lines, they more frequently resort to entertain a multiplicity of voices in their heteroglossic expansion, engaging alternative positions of other members of the community. In the case of acknowledgement, it is noteworthy that all instances refer to the writers' previous works. This may be interpreted as an effort to highlight their own background in the discipline, so as to build confidence in their readers by guaranteeing a positive outcome for the project for which the funding is being requested.

As to other instances of heteroglossia, the very frequent use of non-integral citations observed in the texts seems to be an attempt to contribute to consensual disciplinary knowledge rather 
than to engage in dialogism. The highly recurrent use of this type of citations appears to be typical in the disciplines of Chemistry and Physics, though not necessarily so in other fields of human knowledge.

The results of this work are in accordance with previous contributions to the understanding of the interpersonal resources used to construe stance in academic written discourse in the sense that authors make use of a wide variety of lexico-grammatical tools (see Miller, 2004; Hood, 2004). With only two texts under analysis, this study is far from making generalizations concerning NNESs grant proposal writing. Nevertheless, it may offer useful data for pedagogical applications.

Success in obtaining international funding for the implementation of research projects may be the result of an interplay of a great variety of factors. The results of this study contribute to an understanding of interpersonal positioning in the scientific community through the use of heteroglossic strategies. There is no attempt to imply that the achievement of the social purpose of this genre is a direct consequence of this single factor; writing proposals such as the ones under analysis constitutes a very complex process. Nevertheless, the role of evaluative resources cannot be underestimated.

As to the applications, the texts presented certain characteristics which might be considered as surmountable limitations if the right coaching at the level of implementation of appraisal resources is provided. One specific example of the pedagogical derivations drawn from this study relates to the high frequency of non-integral citations identified, which show some degree of heteroglossic engagement, but slightly evaluative. Researchers may be instructed not only to incorporate other voices but to appraise them as well. This would help them become aware of the ways in which they establish a dialog with other professionals, and have access to a variety of linguistic resources to be able to show a more critical attitude, avoiding a potential tendency to be rather indulgent with their colleges' views. Another pedagogical implication is that grant proposal writers may benefit from considering their potentially varied audiences, maintaining a stance of openness to other voices from diverse potential affiliation networks.

Future studies may focus on the analysis of researchers' linguistic awareness of their interpersonal positioning as well as on the specifics of the writing and editing processes. It may also be of relevance to conduct further research on this relatively neglected genre from a functional perspective, specifically in relation to the other Appraisal systems which this investigation did not include -ATTITUDE and GRADUATION- to better understand how writers construct and negotiate their evaluative stance. 


\section{Acknowledgements}

The authors would like to thank SeCyT - Universidad Nacional de San Luis, Argentina for providing financial support, and the researchers who made unconditional contributions to this study.

\section{REFERENCES}

Bakhtin, M. (1982). The dialogic imagination. University of Texas Press. Austin: TX.

Connor, U. \& Mauranen, A. (1999). Linguistic analysis of grant proposals: European Union research grants. English for Specific Purposes, 18(1), 47-62.

Johns, A. (1993). Written argumentation for real audiences: Suggestions for teacher research and classroom practice. TESOL Quarterly, 27(1), 75-90.

Halliday, M.A.K. (1985). An introduction to functional grammar. London: Edward Arnold.

Halliday, M.A.K. (1994). An introduction to functional grammar (Second edition). London: Edward Arnold.

Halliday, M.A.K. \& Mathiessen, C. (2004). An introduction to functional grammar (Third edition). London: Edward Arnold.

Hood, S. (2004). Appraising research: Taking a stance in academic writing. University of Technology, Sydney.

Hood, S. \& Martin, J. R. (2005). Invocación de actitudes: El juego de la gradación de la valoración en el discurso. Revista Signos, 38(58), 195-220.

Hunston, S. (1993). Evaluation and ideology in scientific writing. In Ghadessy, M. (Ed.), Register analysis: Theory and practice (pp. 57-73). London: Pinter Publishers.

Hyland, K. (1996a). Writing without conviction? Hedging in science research articles. Applied Linguistics, 17(4), 433-453.

Hyland, K. (1996b). Talking to the academy forms of hedging in science research articles. Written Communication, 13(2), 251-281.

Hyland, K. (1998a). Hedging in scientific research articles. Amsterdam: John Benjamins.

Hyland, K. (1998b). Boosting, hedging and the negotiation of academic knowledge. Text, 18(3), 349-382.

Hyland, K. (2000). Persuasion in academic articles [on line]. Retrieved from: <http://sunzi1. lib.hku.hk/hkjo/view/10/1000158.pdf>.

Hyland, K. (2004). Disciplinary discourses. Social interactions in Academic Writing. Ann Arbor: The University of Michigan Press. 
Martin, J. R. (1992). English text: System and structure. Amsterdam: Benjamins.

Martin, J.R. (2000). Beyond exchange: Appraisal systems in English. In S. Hunston \& G. Thompson (Eds.), Evaluation in text: Authorial stance and the construction of discourse (pp. 142-175). Oxford: Oxford University Press.

Martin, J. R. \& Rose, D. (2003). Working with Discourse: Meaning beyond the Clause. London and New York: Continuum.

Martin, J. R. \& Rose, D. (2007). Genre relations: Mapping culture. London: Equinox.

Martin, J. R. \& White, P. R. (2005). Language of evaluation: Appraisal in English. London: Palgrave Macmillan.

Martínez, I. A. (2001). Impersonality in the research article as revealed by analysis of the transitivity structure. English for Specific Purposes, 20, 227-247.

Martínez, I. A. (2003). Aspects of theme in the method and discussion sections of biology journal articles in English. Journal of English for Academic Purposes, 2, 103-124.

Miller, D. (2004). “...to meet our common challenge”: ENGAGEMENT strategies of alignment and alienation in current US international discourse. Textus, XVIII(1), 39-62.

Myers, G. A. (1989). The pragmatics of politeness in scientific articles. Applied Linguistics, 10(1), 1-35.

Myers, G. A. (1990). Writing biology: Texts in the social construction of scientific knowledge. Madison: University of Wisconsin Press.

Myers, G. A. (1991). Lexical cohesion and specialised knowledge in science and popular science texts. Discourse Processes, 14(1), 1-26.

Ponticelli, A., Pascual, M. \& Unger, L. (2005). Grant proposal como género académico: Las estrategias de persuasión. III Coloquio Nacional de Investigadores en Estudios del Discurso. Universidad Nacional del Sur. Argentina [on line]. Retrieved from: http://www. fl.unc.edu.ar/aledar/hosted/3ercoloquio/514.pdf

Salager-Meyer, F. (1990). Discoursal flaws in Medical English abstracts: A genre analysis per research- and text-type. Text, 10(4), 365-384.

Salager-Meyer, F. (1994). Hedges and textual communicative function in medical English written discourse. English for Specific Purposes, 13(2), 149-171.

Salager-Meyer, F. (1997). I think that perhaps you should: A study of hedges in written scientific iscourse. In Miller T. (Ed.), Functional approaches to written texts: Classroom applications (pp. 5-118). Washington: United States Information Agency English Language Programs.

Swales, J. (1990). Genre analysis: English in academic and research settings. Cambridge: CUP. 
Swales, J. (1996). Occluded genres in the academy: The case of the submission letter. In E. Ventola, Eija \& A. Mauranen (Eds.), Academic writing: Intercultural and textual issues (pp. 45-58). Amsterdam: John Benjamins.

White, P.P.R. (2001). An introductory tour through Appraisal Theory [on line]. Retrieved from: www.grammatics.com/Appraisal/AppraisalOutline/AppraisalOutline.doc

White, P.P.R. (2002). Appraisal: The language of attitudinal evaluation and intersubjective stance [on line]. Retrieved from: www.grammatics.com/Appraisal

White P.R.R. (2003a). Beyond modality and hedging: A dialogic view of the language of intersubjective stance. Text [special issue on Appraisal], 23(2), 259-284.

White.P.R.R. (2003b). Appraisal and the resources of intersubjective stance [on line]. Retrieved from: www.grammatics.com/appraisal

\section{NOTE}

1 Examples taken from http://www.grammatics.com/Appraisal/AppraisalGuide/Framed/Frame. $\mathrm{htm}$ 